\title{
Violence as a Dimension of Poverty ${ }^{1}$ The Case of Colombia
} Ágnes DEÁK ${ }^{20}$

\begin{abstract}
Latin America continues to face a number of socio-economic challenges, despite being a middle-income region and the fact that it experienced alternative forms of development during the pink-tide era. The current increasing levels of poverty, inequality, violence and the harmful effects of extractive production on the environment and traditional rural communities represent a new situation at both regional and national levels. The concept of multidimensional poverty is an increasingly accepted approach to a better understanding of the characteristics and living conditions of vulnerable social groups: In these groups, violence is one of the dimensions that has received little attention so far. The paper focuses on the following questions: What is the relation between human security and human development concepts? How are violence and multidimensional poverty interconnected? What kinds of institutional and economic mechanisms sustain their complex relation? The article explores the origins of the human security and human development approaches and their relation to multidimensional poverty. The study relies on analysing academic and official government documents and papers by international organisations synthesising the evolution of the two branches. The case study of Colombia based on statistical data offers evidence about the complexity of the interconnectedness of security, human rights and development processes in different territorial, ethnic and social contexts. The analysis also reveals links between shortcomings in the institutional system and deficiencies in measuring poverty in persistent deprivation of marginalised social groups.
\end{abstract}

Keywords: violence, multidimensional poverty, human security, human development, Colombia

I wish to thank Judit Ricz and Dávid Selmeczi for their suggestions, insightful comments and help.

PhD student, Corvinus University Budapest, Doctoral School of International Relations and Political Science,

World Economics subprogram, e-mail: agnesdeak@yahoo.com 


\section{Introduction}

Violence is a complex phenomenon manifested in interstate relations, public and private realms, characterised by multiple causes and forms rooted in systems and processes of dominance. To explore all its aspects affecting the population as a whole and each individual is difficult due to objective and subjective elements with indirect apparent forms, which can be structural and symbolic. The concept of structural violence, as Johan Galtung proposes, is caused by a whole set of structures, both physical and organisational, that impedes the satisfaction of basic human needs such as survival, identity, well-being or freedom. ${ }^{3}$ As introduced by Pierre Bourdieu, symbolic violence refers to an invisible nature of violence, which is implicit and conceals the fundamental interconnectedness of force relations appearing through acts or conventional behaviour patterns. Thus it recognises structural violence and reinforces it. ${ }^{4}$ These two approaches clearly reflect the impenetrability of violence in diverse spheres of reality and its impact at different levels: violence can happen not just among states, but between individuals and different social groups, frequently related to discrimination or to certain institutions having an impact on everyday life routine, opportunities and social cohesion, thus on the democratic system.

While interstate and armed conflicts had been emphasised during decades after World War II, as Mary Kaldor expresses in the concept of "new war", new forms of violence have emerged in recent decades, in which the boundaries between state and non-state actors, public and private spheres are blurred, the majority of affected are civilians. In addition, criminal political economy is maintained by organised crime groups to generate revenue through violent activities. ${ }^{5}$ As data shows, the number of victims of criminal acts significantly exceeds the number of those killed in armed conflict or as victims of terrorism. Of particular note is the number of acts of violence resulting in the deaths of organised crime, which account for 20 per cent of all homicide cases. ${ }^{6}$ The recognition of the crucial role of violence appears in the Sustainable Development Goals agenda adopted by the United Nations in 2015, as well. In the Agenda, the international political community set out its objectives in target 16.1 by stating: "Significantly reduce all forms of violence and related death rates everywhere."

At the same time, there has been a change of approach in the interpretation of security. Given the rise of chronic insecurity caused by a number of threats, a shift in the concept has brought violence, and insecurity experienced and interpreted at the individual level into focus within the human security framework as Mahbub ul Haq encapsulates it:

\footnotetext{
Johan Galtung, ‘Violence, Peace, and Peace Research', Journal of Peace Research 6, no 3 (1969), 167-191. Pierre Bourdieu, 'Sur le pouvoir symbolique’, Annales 32, no 3 (1977), 405-411.

7 UN, 'Transforming Our World: The 2030 Agenda for Sustainable Development: Sustainable Development Knowledge Platform', 2015. Identified as one of its indicators defining in SDGs 16.1.1 as: “Number of victims of intentional homicide per 100,000 population, by sex and age.” This target is a significant step forward from the previous UN agenda, the Millennium Development Goals, which set only 8 goals to be achieved and did not include the emphasis on action against violence and improvement of the justice system and strong institutions. See www.un.org/millenniumgoals/
} 
"Security of all the people everywhere - in their homes, in their jobs, in their streets, in their communities, in their environment [...] is not a concern with weapons [...]. It is a concern with human dignity." 8 The human security (HS) paradigm emerged in parallel with the sustainable human development (HD) and the capability approach. A development model, its fundamental goal is to enhance human life and interprets development as offering opportunities, thus freedom to the individuals to unfold their capabilities instead of defining it as mere economic growth at an aggregate level. The HS concept focuses on "downside risks" and vulnerabilities that particularly affect disadvantaged groups in society, such as the extremely poor and socially needy people. The concept of poverty based on the HD approach has become widely accepted among the majority of scholars and also the public spheres as a multidimensional phenomenon taking many forms, as it is argued by Amartya Sen: "The role of income and wealth [...] has to be integrated into a broader and fuller picture of success and deprivation." ${ }^{9}$ As deprived groups in society are particularly affected by threats, poverty is a highly important risk factor related to crime and victimisation at various levels. At the individual level, people may opt for violent crime to survive or to be subject to it as victims due to inefficient law enforcement and regulatory system. High level of violence affects individual property rights and deteriorates the business environment and activity leading to poverty. This paper aims to reveal the complexity of interconnectedness of violence and poverty in the Colombian context considering HS and HD complementary to each other and their increasingly important joint role in national public policies to address many forms of deprivations of its population. ${ }^{10}$

Colombia serves as a particularly interesting case in terms of examining these two facets of reality for several reasons: 1 . Colombia is characterised by endemic violence with national homicide rate 25 (2019) and 23.7 (2020) per 100,000 persons, ${ }^{11}$ even overpassing the respective data of Latin America and the Caribbean as the most violent region in the world, considering its high rates of homicides, which is almost three times the world average (17.2 homicides and 6.1 homicides for every 100,000 people, respectively in 2017). ${ }^{12}$ Latin America, with its economic growth becoming a middle-income region with still the highest homicide rate in the globe since reliable records from 1990 shows an outlier case and Colombia as an upper-middle-income country even a special one. 2. Conventional wisdom is that long-standing problems of violence and poverty are the root causes of migrant waves, which are one of the most important global emergencies. Intraregional migration within South America is also strikingly high, with the majority of international

8 Mahbub ul Haq, Reflections on Human Development (Oxford University Press, 1995), 15-16.

$9 \quad$ Amartya Sen, Development as Freedom (Oxford - New York: Oxford University Press, 1999 ), 37.

10 Just as Galtung's interpretation of positive peace includes the concept of sustainable economic development, among others e.g. democratic governance, transparent institutional system, social justice and equality or environmental protection. Johan Galtung, Theories of Peace. A Synthetic Approach to Peace Thinking (Oslo, International Peace Research Institute, 1967), 138. The relationship between development and security appears in Mahbub ul Haq's interpretation as well, "security through development not through arms". Haq, Reflections, 115; UNDP, Human Development Report 1994 (New York: Oxford University Press, 1994).

11 UN HRC, Situation of Human Rights in Colombia - Report of the United Nations High Commissioner for Human Rights (A/HRC/46/76) (UN, February 2021).

12 UNODC, Global Study on Homicide 2019. The latest data presented in the document is from 2017. 
migrants moving within the subregion countries. Colombia is a special example for the theory even for international migration in the subregion and with more than 5.7 million internally displaced people until the end of 2018 - the second highest of its kind in the world. ${ }^{13}$ 3. The negative socio-economic effects of former neoliberal policies introduced under the Washington Consensus have added up to inherited development challenges, such as permanent high levels of informality and lack of access to services. Colombia has one of the highest rates of informal employment in the region with more than 50 per cent. ${ }^{14} 4$. Latin America was the pioneering region ${ }^{15}$ where the concept of multidimensional poverty was first introduced into the measurement, such as Colombia in 2011. In the last decade, several countries in the region have paid particular attention to designing their own public policies and national strategies to reduce poverty based on information revealed by new multidimensional poverty measurements (on the characteristics of poverty at local and regional levels.) 5. As global poverty research confirms, there is an increasing emphasis on subnational concerns to address poverty challenges within a country due to the highly territorial feature of poverty distribution. ${ }^{16}$

This study provides a critical review of academic literature and expert documentation. The analysis of the Colombian case is based on official expert and ministerial, governmental and national and international NGOs, United Nations offices publications, documenting the advancement of the country-specific phenomenon, which also provided the opportunity to have a deep insight into the dynamics of processes. In addition, statistical data and publications were also analysed, mainly from the Colombian National Statistical Office (DANE ${ }^{17}$ by its initials in Spanish) and several ministries.

The paper includes four parts in addition to this introduction. The first provides an overview of the theories of HS and HD. The following part presents the current aspects of violence and poverty in Colombia, and the next part reveals the dynamics related to violence and poverty. The final part concludes.

\section{Human security and sustainable human development}

The discourse on security is inevitable and repeatedly emerges in the academic or public debates in relation to many global phenomena for various reasons. First, in the age of multiple interconnectedness, the external and internal distinction is disappearing. Equally, the threats themselves have a more global attitude. The current increasingly frequent and

13 WMR, World Migration Report 2020 (Geneva: International Organization for Migration, 2020), 103. In the same year, approximately 139,000 Colombians lived as refugees or in refugee-like situations abroad, which is a significant decrease from more than 190,000 in 2017 and 300,000 in 2016 (Ibid).

14 OECD, 'Portraits of Informality’.

15 Julio Boltvinik, 'Medición Multidimensional de La Pobreza. AL de Precursora a Rezagada', Revista Sociedad y Equidad, no 5 (2013).

16 Ravi Kanbur and Andy Sumner, 'Poor Countries or Poor People? Development Assistance and the New Geography of Global Poverty', Journal of International Development 24, no 6 (2012), 686-695.

17 See https://dane.gov.co/index.php/estadisticas-por-tema/pobreza-y-condiciones-de-vida/pobreza-y-desigualdad /pobreza-monetaria-y-multidimensional-en-colombia-2019 
ubiquitous climate and health crisis or the operations of transnational organised crime groups indicate that the state alone cannot be an adequate, single relevant actor. ${ }^{18}$

Second, the weak institutions in relation to the absence of the rule of law within the state creates a destabilised context (political, social). It causes insecurity perception for the citizens and has spillover effects on their survival and well-being. ${ }^{19}$ Although the idea of HS and HD was conceived in the 1990s and stems from the same seed planted by Mahbub ul Haq, both as normative claims having become part of mainstream international policy, even later have followed a separate path of acceptance by academia, government agencies and multilateral organisations.

The concept of HS first appeared in the Human Development Report in $1994{ }^{20}$ published by the United Nations Development Programme. As an agenda-setting document for the next year World Summit for Social Development, proposed new foundations, namely security and sustainability, for the post-Cold War period in the international cooperation. The two main elements of HS as a basic idea already appeared as early as the founding of the United Nations, in 1945 in a speech by the U.S. Secretary of State (highlighting President F. D. Roosevelt's 1941 vision of a future for humanity based on four fundamental freedoms) stating: "The battle of peace has to be fought on two fronts. The first is the security front, where victory spells freedom from fear. The second is the economic and social front, where victory means freedom from want. Only victory on both fronts can assure the world of enduring peace." ${ }^{21}$ In the report, HS was conceptualised in seven categories: economic security, food security, health security, environmental security, security of individual persons, security of the community and political security, and entered the academic and government agendas with discussion. The interpretations about the security concept in the "new war" era have been extended in four directions, summarised by Emma Rothschild. "Downward" is from the security of states to groups and individuals, "upward" from national to international level, even to the biosphere, "horizontally" from military to political, economic, social, environmental or human security, and "multi-sectoral” way as from national political actors to international institutions, local and regional bodies, the NGOs, the media and the market, as well. ${ }^{22}$ The original proposal of the United Nations Development Programme evolved and incorporated the human dignity aspect due to the spread and strengthening of the protection and promotion of human rights. It encompasses a complex approach that implies freedom from fear (threats to survival e.g. violence, physical abuse or death), freedom from want (threats from livelihoods e.g. food insecurity, unemployment, etc.), and living in dignity (to be free from e.g. discrimination, exclusion, lack of human rights). Its main characteristics are as follows: 1 . universal: relevant for developing and developed countries; 2. interconnectedness: threats are interrelated

18 Related to this is Ulrich Beck's concept of the Risk Society, according to which new elements appearing in technological progress are sources of potential danger, and thus the results of modernity itself. It fits into this process that cyberattacks, biological issues, both in theory and in policy, are within the scope of security.

19 See Paul Collier, The Bottom Billion: Why the Poorest Countries are Failing and What Can Be Done About It (New York: Oxford University Press, 2008).

20 UNDP, HDR 1994.

21 Ibid. 3.

22 Emma Rothschild, 'What Is Security?', Daedalus 124, no 3 (1995), 55. 
and in general have a domino effect which requires a comprehensive approach and multidimensional analysis; 3. emphases prevention to avoid major threats and to build resilience; 4 . people-centeredness: that individuals and communities can act as agents and beneficiaries; 5 . empowerment and protection also became pillars of propositions in the Commission on Human Security's 2003 report. ${ }^{23}$

Mahbub ul Haq's concept of security puts people in focus. The same approach appears in his interpretation of development, as he summarised that a country's true values are its people, and they are the means and ends of economic development. The basic idea of HD, as it is stated in the first Human Development Report, "here denotes both the process of widening people's choices and the level of their achieved well-being". ${ }^{24}$ The goal is to equally realise people's capabilities in all areas of their lives, political, economic, cultural and social, in the present and the future. It is formulated on Amartya Sen's theory called the capability approach, which focuses on people's capabilities and to enable people to have an agency about their own lives in their community. In such a context, development is based on people's freedom who have to decide for themselves the kind of development they want. Since people and communities determine it and thus the tools leading to it. The agency is closely linked to the opportunities that enable individuals to have a dignified life, e.g. an education. Still, the agency also means that they shape the environment in which they can have a fulfilled life. The perspective of HD is multidimensional, encompassing different public policies instead of concentrating on only one type of policy such as health, education or fiscal policy. In Sen's theory, functionings and capabilities are fundamental elements. The former are things that people have reason to value, and the latter refers to freedom that allows them to experience different functions. ${ }^{25}$ In the HD approach, in addition to the goal of development, the process itself is similarly emphasised, about which ul Haq makes four important statements: equity, efficiency, participation and sustainability. ${ }^{26}$ Sen's invention of the capability approach and development was decisive in interpreting poverty, which placed the previous income-based approach in a multidimensional perspective.

As a result of the 2008-2009 global economic crisis, the Stiglitz-Sen-Fitoussi report made it clear that a new approach (including new statistical methods and data) is required to appropriately map socio-economic processes and thus to provide adequate information to decision-makers to elaborate proper public policies. As the report puts it: "What you measure affects what you do; and if our measurements are flawed, decisions may be distorted." ${ }^{27}$ Reflecting the report, new initiatives were launched, such as the Global Multidimensional Poverty Index of the Oxford Poverty and Human Development Initiative, ${ }^{28}$ inspiring the elaboration of national poverty indices, especially in Latin

23 Commission on Human Security, Human Security Now: Protecting Empowering People (UN, 2003).

24 United Nations, Human Development Report 1990. Published for the United Nations (New York) Development Programme (New York: Oxford University Press, 1990), 10.

25 Sen, 'Development as Freedom'.

26 Haq, Reflections.

27 Joseph E Stiglitz, Amartya Sen and Jean Fitoussi, The Measurement of Economic Performance and Social Progress Revisited (Paris: Commission on the Measurement of Economic Performance and Social Progress, 2009), 7.

${ }_{28}$ Sabina Alkire and James Foster, 'Counting and Multidimensional Poverty Measurement', Journal of Public Economics 95, no 7-8 (2011), 476-487. 
America. Although these indices provide a much more detailed picture of deprivations of people living in poverty, they still lack measurement of critical dimensions, such as violence revealed in global participatory research about vulnerable social groups worldwide. ${ }^{29} \mathrm{HS}$ is concerned with basic needs as human rights and as "downside risks" such as threats embedded in people's everyday lives hindering them from unfolding their functions safely. United Nations Development Programme reports of the past decade show an increasing focus on attempts with little success to tackle personal and citizen security issues regarding organised physical violence or threats to personal safety and property. ${ }^{30}$ I argue that HS and HD complement each other. They form a comprehensive, integrated approach while exploring the shortcomings of socio-economic-institutional complexity and revealing subregional and horizontal inequalities. As a holistic approach it can be suitable to elaborate the necessary context-specific, preventive measures and public policies based on adequate measurement.

\section{Violence and poverty in Colombia}

Although violence was present in Latin America in pre-Columbian cultures, the emergence of structural violence can be linked to the establishment of colonialism, mainly related to the extermination of indigenous communities and partly to the forcible importation of Africans by the transatlantic slave trade. In later centuries, the civil wars and in the mid$20^{\text {th }}$ century, the successive dictatorships with brutal secret service apparatus, organised armed insurgency groups all reinforced the role of violence and arms. Violence does not affect and characterise the countries in the region in the same way; Colombia ranks $10^{\text {th }}$ in the South American region on the Global Peace Index, and $144^{\text {th }}$ in the global ranking. ${ }^{31}$ Colombia today is characterised by many forms of violence that permeate society in its socio-economic and political aspects. However, different social groups are affected in diverse ways and degrees. The violence began to have a major impact on the country, especially from the second half of the $20^{\text {th }}$ century, beginning in the period 1948-1960, which is specifically referred to in Colombian history as "La Violencia” [The Violence], with around 200,000 victims, mainly in rural areas. ${ }^{32}$

29 Deepa Narayan et al., Voices of the Poor: Can Anyone Hear Us? (World Bank, 2000).

30 Des Gasper and Oscar A Gómez, 'Human Security Thinking in Practice: "Personal Security”, "Citizen Security” and Comprehensive Mappings’, Contemporary Politics 21, no 1 (2015).

31 Institute for Economics and Peace, Global Peace Index 2021: Measuring Peace in a Complex World (Sydney: June 2021).

32 Bruce M Bagley and Jonathan D Rosen, Colombia's Political Economy at the Outset of the Twenty-First Century: From Uribe to Santos and Beyond (Lexington Books, 2015). 


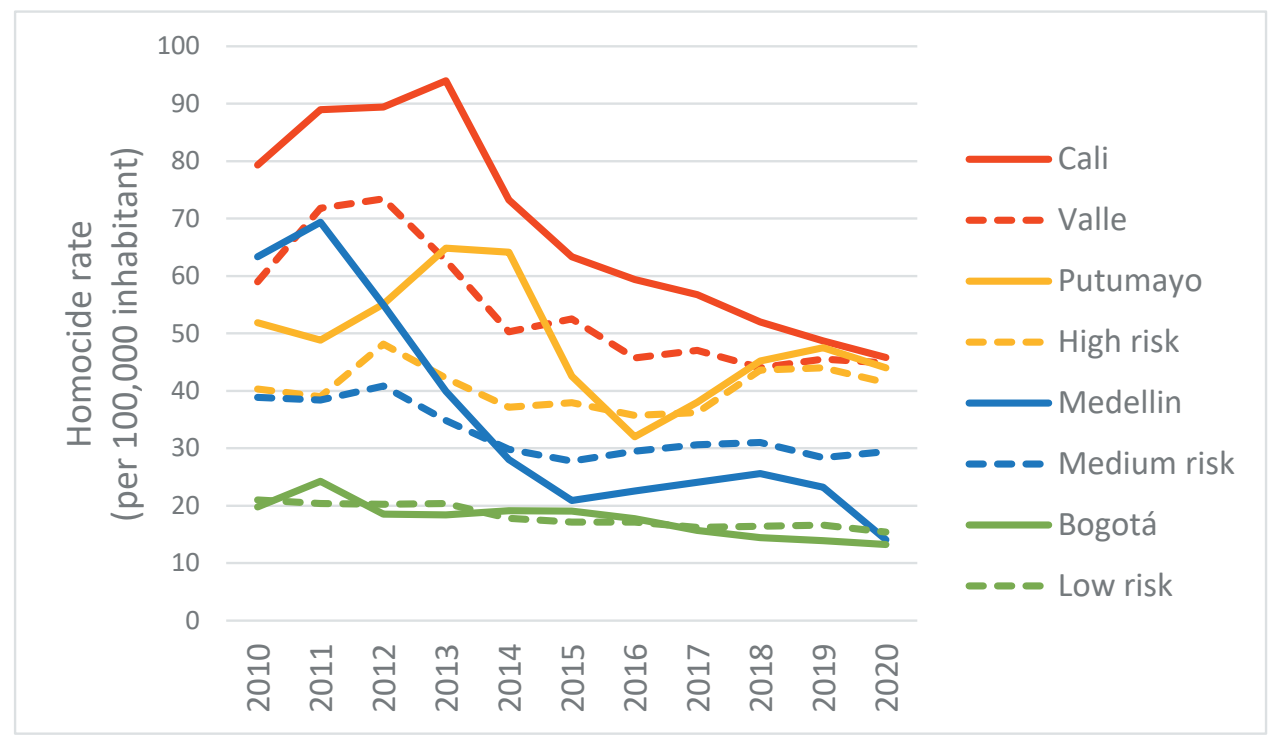

Figure 1: Homicide rate in Colombia 2010-2020

Low risk: Amazonas, Atlántico, Bolívar, Boyacá, Caldas, Casanare, Cesar, Córdoba, Cundinamarca, Guainía, Guajira, Huila, Magdalena, Santander, Sucre, Tolima, Vaupés, Vichada Medium risk: Meta, Nariño, Norte de Santander, Risaralda, San Andrés

High risk: Antioquia, Arauca, Caquetá, Cauca, Chocó, Guaviare, Quindío

Source: Compiled by the author based on the online data of the 'Policía Nacional de Colombia', s. a.

Aggregate data in Figure 1 shows a declining trend at the national level in the homicide rate over the past decade, albeit with significant variation across different country departments. The provinces with high homicide ratios are closer to the southern border of the country and those in the Pacific and Amazon regions, especially Putumayo, Valle de Cauca, Cauca, Antioquia and Arauca departments. At the same time, aggregate data, whether for mortality or other acts of violence, obscures the attributes of dynamics related to territory, ethnicity, and social group characteristics and special features. Despite the declining trend, specific data in Figure 2 show one of the most striking figures: the attacks on and killings of environmental activists and human rights defenders, a record number as Colombia accounts for 30 per cent of all global cases. The country has also experienced a 150 per cent increase compared to the previous year. 


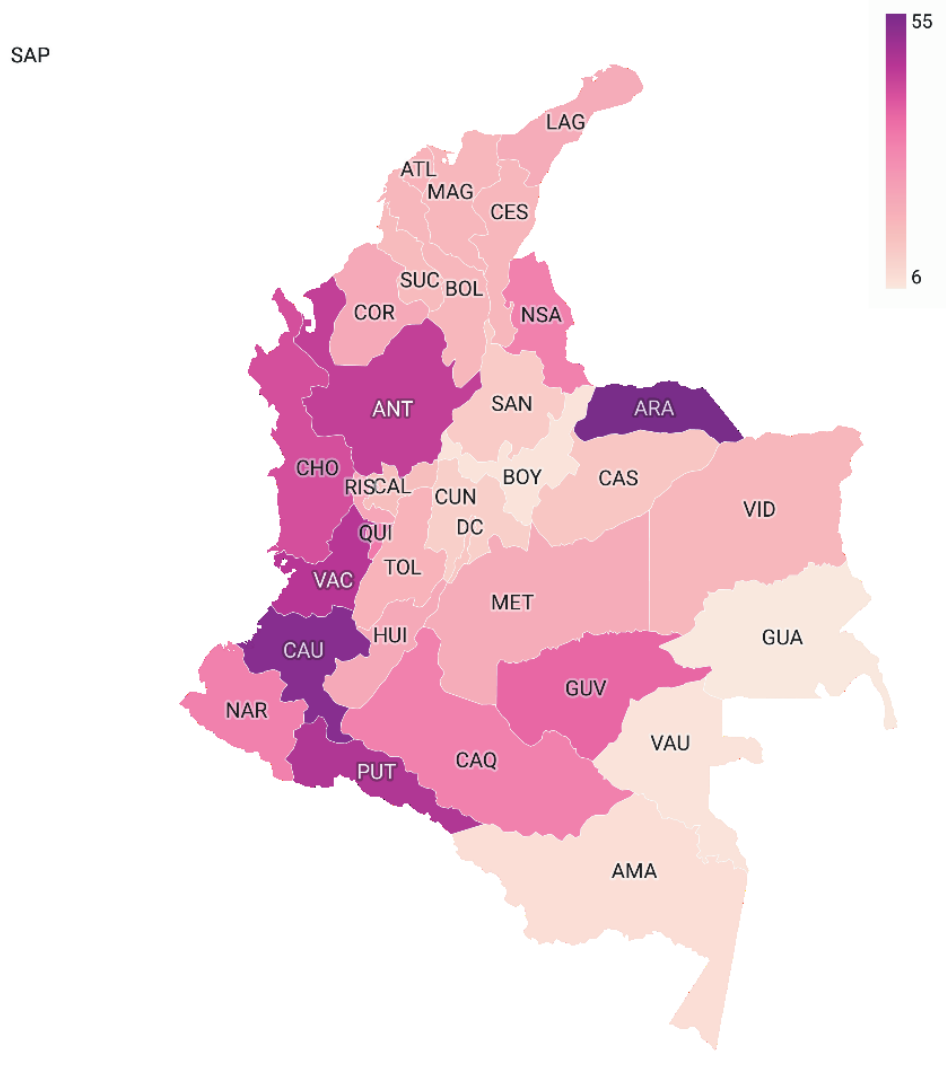

Map 1: Departments and their homicide rate in 2019

Source: Compiled by the author based on the online data of the 'Policía Nacional de Colombia', s. a.

Meanwhile, half of the victims belonged to indigenous communities. ${ }^{33}$ Various human rights organisations have different data on human rights violations and killings (the highest number of 942 aggression). Still, each one reports an intensifying trend, primarily against community and social leaders, whose especially high proportion belongs to ethnic groups. ${ }^{34}$ The severity of the phenomenon is shown by the fact that a demonstration at the national level was organised for the victims and their communities in November 2019. Map 1 shows departments with different homicide rates (2019), while Map 2 shows the territorial distribution of Afro-Colombian and indigenous people and communities. Regarding the last census (2018), we can observe a territorial coincidence.

33 Global Witness, 'Defending Tomorrow', July 2020.

34 See SIADDHH, ‘La Mala Hora Informe Anual 2020’; Business and Human Rights Resource Center, 'Business and Human Rights Defenders in Colombia’, March 2020; UN HRC, Situation of Human Rights in Colombia. 


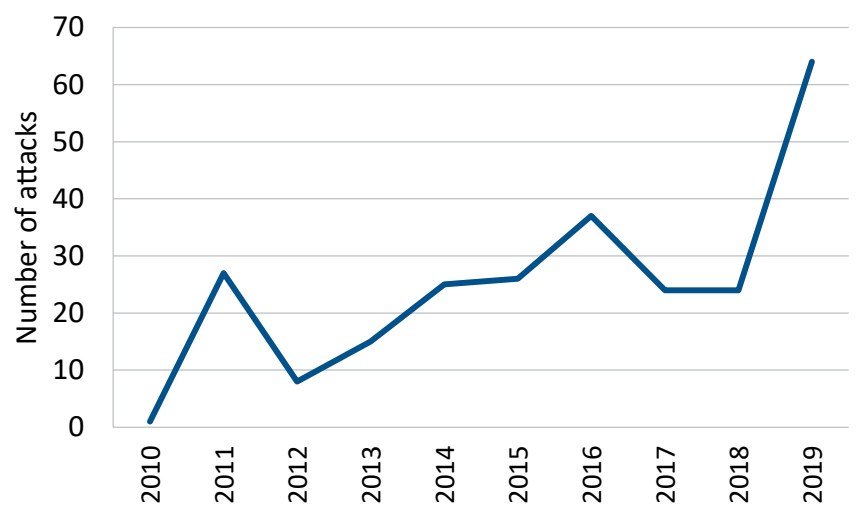

Figure 2: Killings of environmental activists

Source: Compiled by the author based on Global Witness data.

In Colombia, poverty reduction has been identified as one of the key objectives of the 2010 National Development Plan presented by President Juan Manuel Santos. To achieve this, new measurement methods were introduced in 2011. The National Planning Department has elaborated not only a completely new multidimensional poverty measurement but also a new income poverty measurement was put forward. It was explicitly aimed that the measurement should have characteristics that are appropriate for consistent analysis, change in public policy decisions, and a reflection of the current living conditions of Colombians. The final version of the measurement consists of five dimensions: household education conditions, childhood and youth conditions, employment, health and access to public utilities and housing conditions, each defined by five indicators, ${ }^{35}$ whose data source is the Living Standards Measurements Survey. All indicators together determine the national multidimensional poverty index using the Alkire-Foster method. ${ }^{36}$ The index assigns the same weight to each dimension (20 per cent), and the poverty line is considered at one-third of the weighted dimensions. It is important to mention that this is the only measurement in the Latin American region that has put exceptional emphasis on a special dimension, namely the living conditions of children and young people, which reflects the demographic conditions of the country. However, a significant shortcoming is that the dimension of violence and physical security was not included in this measurement. It happened despite the fact of the endemic violence, which has particularly accompanied the modern history of the country, not just prior to the peace agreement with the Revolutionary Armed Forces of Colombia (FARC by its initials in Spanish) in 2016. Empirical research conducted by participatory approach also revealed that for the poor living in Colombia, in addition to livelihood and education, the most significant deprivation is the persistence

35 Roberto Carlos Angulo Salazar, Yadira Díaz Cuervo and Renata Pardo, Índice de Pobreza Multidimensional Para Colombia (Archivos de Economía, Departamento Nacional de Planeación, 7 November 2011). 
of violence and physical vulnerability. ${ }^{37}$ The significance of the new method is shown by the fact that, as an indicator, it is a determining element of a number of important national social policies, such as the poverty and inequality reduction programs (e.g. early childhood care and food security programs) and also the geographical targeting of the conditional cash transfer program called in Spanish "Más Familias en Acción” [More Families in Action]. Figure 3 shows that all forms of poverty, income poverty (including extreme) and multidimensional decreased under the Santos Government in 2010-2018, but the most significant change happened in multidimensional poverty at the national level from 30.4 per cent to 17.8 per cent, while in rural areas from 53.1 per cent to 37.6 per cent.

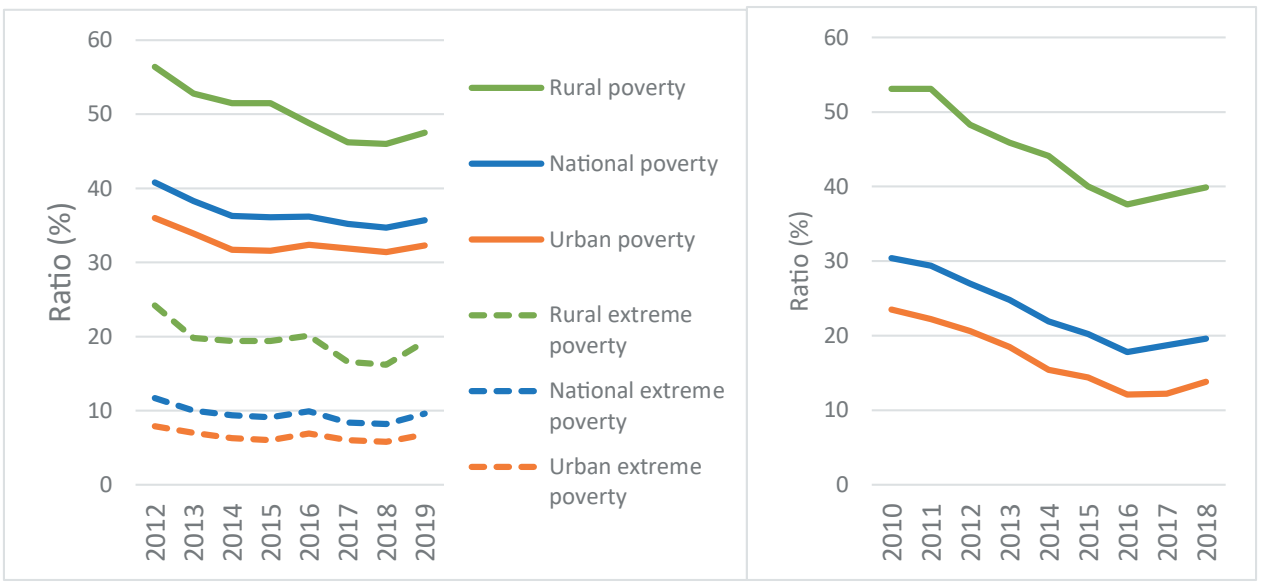

Figure 3: Left: Income poverty and extreme poverty 2012-2019; right: Multidimensional poverty 2010-2018

Source: Compiled by the author based on DANE online data.

After 2018, under the government of Iván Duque, all trends show stagnation and, slightly, deterioration. Map 2 shows poverty and Afro-Colombian and indigenous population distribution regarding the departments. In the map, we can see that it does not coincide with the departments with elevated numbers in the homicide rate, but at the same time coincides with the areas of the Amazon region, where only 3 per cent of the total population lives almost exclusively in small indigenous communities. The Afro-Colombian community is 9.34 per cent; the indigenous is 4.4 per cent from the total population (48 million people). The multidimensional poverty rate of Afro-Colombians is 11 per cent higher than the national level, it is 30.6 per cent and 19.6 per cent, respectively. Nariño, Cauca and Valle del Cauca display the highest difference and the more striking divergences are shown in informal employment and education indicators of the measurement. Indigenous communities show a similar trend of living at an inferior level in all socio-economic indicators than the national average, regarding the new 2018 census data.

37 Jairo A Arboleda, Patti L Petesch and James Blackburn, Voices of the Poor in Colombia: Strengthening Livelihoods, Families, and Communities (Washington, D.C.: World Bank Publications, 2004). 


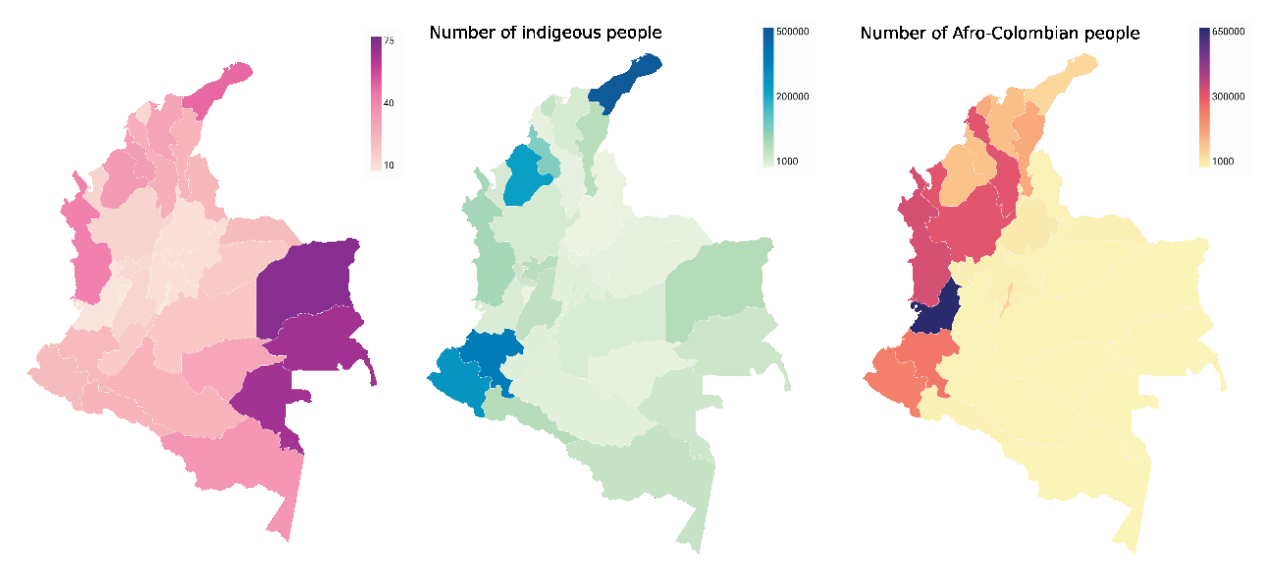

Map 2: Multidimensional poverty distribution and distribution of indigenous and Afro-Colombian people (2019)

Source: Compiled by the author based on DANE online data.

\section{Old-new dynamics behind the scenes}

A number of factors and processes need to be taken into account to understand the background to some particular worsening trend in violence. Colombia is a country with a high-risk factor for climate change, which mainly manifests in floods, landslides and droughts. Especially, livelihoods and food production will become an increasing challenge in rural areas, causing further internal migration. ${ }^{38}$ Despite the commitment of the Colombian Government under President Juan Manuel Santos to manage the climate crisis as part of the peace process in accordance with the Paris Agreement, it has continued to support carbon-intensive mining. (Colombia is among the ten largest coal producers in the world). Moreover, it has boosted the agroindustry, e.g. by planting oil palms and relying on hydroelectric projects. At the same time, data from different sources and current trends show that social conflict is constant in Colombia, partly because of the extraction of natural resources and its negative impacts on the environment and the lives of local, mainly indigenous and Afro-Colombian communities. The conflict is essentially due to the non-compliance with the legal framework of their rights, such as the right of communities to their territory and the institution of prior consultation. These are, in principle, guaranteed by the 1991 Colombian Constitution.

Colombia with 14 other Latin American countries, ratified the institution of prior consultation based on the Convention 169 of the International Labor Organization on

38 UNDP, Mainstreaming Climate Change in Colombia (New York: UNDP Project Team, 2010). 
Indigenous and Tribal Peoples, 1989. The institution is particularly significant since extractive projects are of major importance in terms of the GDP of the countries, but concurrently is a general source of tension and conflictive actions between different social groups in the entire region.

Despite the ratification, the implementation process has encountered several setbacksat many points because the national economy's reliance on natural resources seeks the interests of transnational corporations and business associations. However, the possibility of consultation process under current domestic legal circumstances is increasinglyconstrained, partly due to a lack of political will since the beginning of Iván Duque's government in 2018, which also reflects the asymmetry of power between politicaleconomic elites and the indigenous groups. ${ }^{39}$ In a few cases, the companies themselves contributed to the violence. Still, it is difficult to directly link most of the atrocities on community defenders and environmental activists to the companies as actors. ${ }^{40}$ In 2018 , the current President Iván Duque announced and implemented partly a program in favour of private investment in community areas, proving he has not taken some points of the FARC peace agreement further. Moreover, he tries to handle the ongoing violence caused by the residual guerrilla and armed paramilitary groups through militarism, increasing again the presence of arms in the country as a conflict solution tool.

In Colombia, the oil and mining sector, which already accounted for 32 per cent of the $\$ 14.5$ trillion in FDI inflows in 2019, even before the pandemic, is projected to be the motor of economic recovery from the economic crisis. ${ }^{41}$ Colombia's gold production has grown significantly and steadily over the past decade, thanks to the ever-rising international gold price, which was mainly due to the 2008-2009 financial crisis as a safe form for financial assets (Figure 4).

39 The institution of prior consultation has become a weak or stronginstitutional element to varying degrees in different Latin American countries. See Daniel M Brinks, Steven Levitsky and María Victoria Murillo, The Politics of Institutional Weakness in Latin America (Cambridge University Press, 2020).

40 In a few cases, the companies themselves contributed to the violence, but it is difficult to link most of the atrocities on defenders directly to the companies as actors. $44 \%$ of the atrocities were committed by five companies, which are also the largest mining companies in the country.

41 UNCTAD, World Investment Report 2020: International Production beyond the Pandemic (Geneva - New York: United Nations, 2020). 


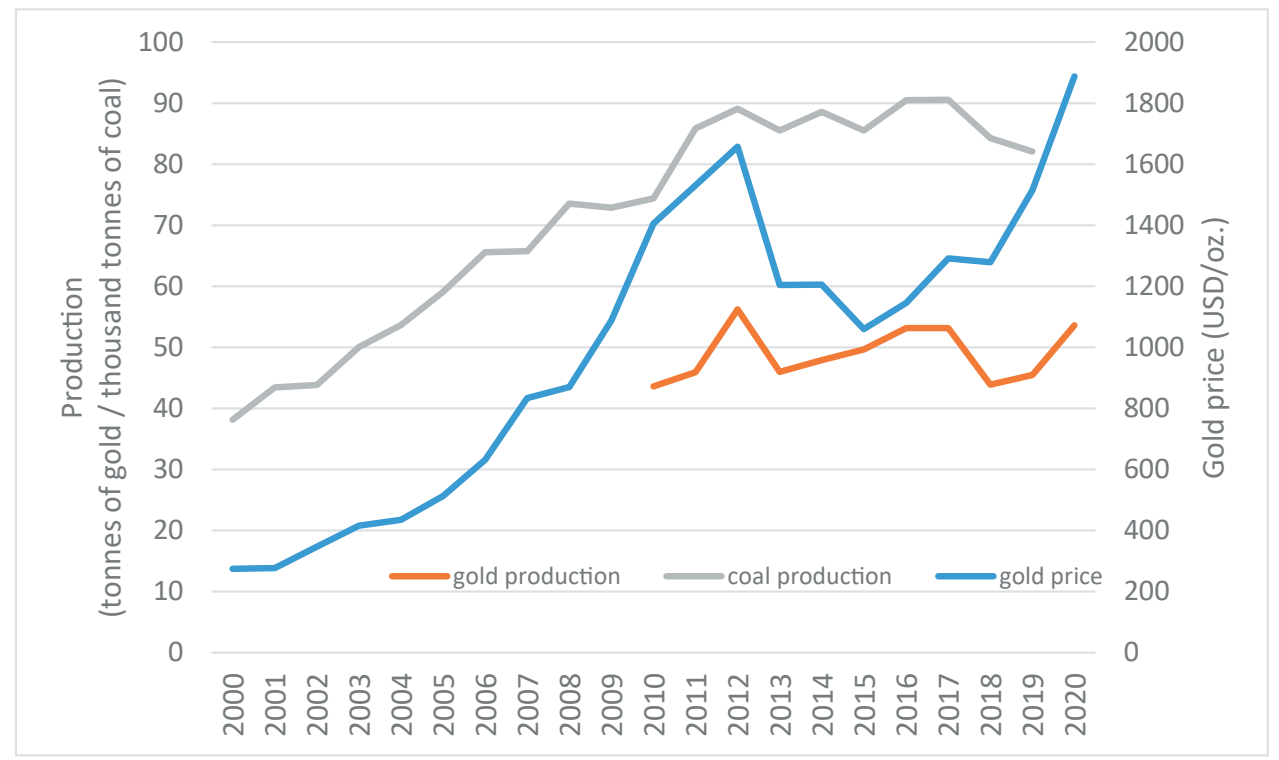

Figure 4: Gold and coal production 2000-2020, gold price 2000-2020

Source: Compiled by the author based on Goldhub and Knoema ${ }^{42}$ online data.

The increased importance of gold is demonstrated by the fact that just like legal mining, illegal gold mining has also been increased in many departments over the last decade. Illegal alluvial gold mining has a significant environmental impact, using heavy machinery and toxic substances, resulting in significant irreversible land and water pollution. In addition to the environmental damage, the social damage is just as significant, as the extraction process and much of its territory are controlled by organised crime groups. These activities are closely linked to other illegal ones such as trafficking in human beings and arms and various forms of threats to local populations, e.g. extortion. In 2020 alluvial gold mining was carried out in 12 departments (out of 32) in 100,752 ha, (an increase of 3 per cent compared to 2019), of which 69 per cent was illegal. Antioquia, Chocó and Bolívar are the three departments with the highest extraction rate, having a share of 88 per cent since 2014. ${ }^{43}$

42 See www.gold.org/goldhub/data/gold-prices, www.gold.org/goldhub/data/historical-mine-production, https:// public.knoema.com/sdybxie/bp-statistical-review-of-world-energy-main-indicators?location=1001250\&variabl $\mathrm{e}=1000050$ \& frequency $=\mathrm{A}$

43 UNODC and Government of Colombia, 'Alluvial Gold Exploitation Evidences from Remote Sensing 2016', May 2018; UNODC and Government of Colombia, 'Colombia Explotación de Oro de Aluvión Evidencias a Partir de Percepción Remota 2020’, July 2021. 
Table 1: Alluvial gold extraction on land (EVOA) between 2014 and 2020

\begin{tabular}{|c|c|c|c|c|c|c|c|c|c|c|}
\hline \multicolumn{11}{|c|}{ Departments affected by EVOA } \\
\hline $\begin{array}{c}\text { National } \\
\text { area } \\
\text { detected for } \\
\text { EVOA }\end{array}$ & \multicolumn{2}{|c|}{78,939 ha } & \multicolumn{2}{|c|}{83,620 ha } & \multicolumn{2}{|c|}{92,046 ha } & \multicolumn{2}{|c|}{98,028 ha } & \multicolumn{2}{|c|}{100,752 ha } \\
\hline Year & \multicolumn{2}{|c|}{2014} & \multicolumn{2}{|c|}{2016} & \multicolumn{2}{|c|}{2018} & \multicolumn{2}{|c|}{2019} & \multicolumn{2}{|c|}{2020} \\
\hline & EVOA & $\begin{array}{c}\text { Total } \\
\text { national }\end{array}$ & EVOA & $\begin{array}{c}\text { Total } \\
\text { national }\end{array}$ & EVOA & $\begin{array}{c}\text { Total } \\
\text { national }\end{array}$ & EVOA & \begin{tabular}{|c|} 
Total \\
national
\end{tabular} & EVOA & \begin{tabular}{|c|} 
Total \\
national
\end{tabular} \\
\hline Department & & $\%$ & (ha) & $\%$ & (ha) & $\%$ & & $\%$ & & \\
\hline Chocó & 36,185 & $46 \%$ & 33,024 & $39 \%$ & 35,194 & $38 \%$ & 35,105 & $36 \%$ & 36,552 & $36 \%$ \\
\hline Antioquia & 26,323 & $33 \%$ & 30,897 & $37 \%$ & 36,447 & $40 \%$ & 40,201 & $41 \%$ & 40,890 & $41 \%$ \\
\hline Bolívar & 7,361 & $9 \%$ & 7,820 & $9 \%$ & 8,913 & $10 \%$ & 10,642 & $11 \%$ & 10,583 & $11 \%$ \\
\hline Cauca & 1,408 & $2 \%$ & 3,702 & $4 \%$ & 3,004 & $3 \%$ & 2,697 & $3 \%$ & 2,807 & $3 \%$ \\
\hline Córdoba & 3,544 & $4 \%$ & 3,592 & $4 \%$ & 3,982 & $4 \%$ & 4,976 & $5 \%$ & 4,975 & $5 \%$ \\
\hline Nariño & 1,676 & $2 \%$ & 2,677 & $3 \%$ & 2,921 & $3 \%$ & 3,171 & $3 \%$ & 3,374 & $3 \%$ \\
\hline Valle & 1,570 & $2 \%$ & 1,023 & $1 \%$ & 889 & $1 \%$ & 608 & $1 \%$ & 765 & $1 \%$ \\
\hline Others & 872 & $1 \%$ & 885 & $1 \%$ & 696 & $1 \%$ & 626 & $1 \%$ & 807 & $1 \%$ \\
\hline \multirow{2}{*}{\multicolumn{3}{|c|}{ Special Management Areas }} & \multicolumn{4}{|c|}{ Areas EVOA 2016} & \multicolumn{4}{|c|}{ Areas EVOA 2020} \\
\hline & & & \multicolumn{2}{|c|}{ EVOA (ha) } & \multicolumn{2}{|c|}{ National \% } & \multicolumn{2}{|c|}{ EVOA (ha) } & \multicolumn{2}{|c|}{ National \% } \\
\hline \multicolumn{3}{|c|}{$\begin{array}{l}\text { Afro-Colombian Community } \\
\text { Territories }\end{array}$} & \multicolumn{2}{|c|}{34,858} & \multicolumn{2}{|c|}{$42 \%$} & \multicolumn{2}{|c|}{41,006} & \multicolumn{2}{|c|}{$40 \%$} \\
\hline \multicolumn{3}{|c|}{$\begin{array}{l}\text { National Natural Parks and } \\
\text { Protected Areas }\end{array}$} & & ,887 & $5 \%$ & & & ,459 & 60 & \\
\hline \multicolumn{2}{|c|}{ Indigenous Reserves } & & & \begin{tabular}{|l|l}
780 \\
\end{tabular} & $1 \%$ & & & 627 & $<19$ & \\
\hline & & \multicolumn{4}{|c|}{ EVOA under legal figures 2016} & \multicolumn{5}{|c|}{ EVOA under legal figures 2020} \\
\hline \multicolumn{2}{|c|}{ Without figures of law } & \multicolumn{4}{|c|}{$66 \%$} & \multicolumn{5}{|c|}{$69 \%$} \\
\hline \multicolumn{2}{|c|}{$\begin{array}{l}\text { Environmental and/or } \\
\text { technical licenses }\end{array}$} & \multicolumn{4}{|c|}{$27 \%$} & \multicolumn{5}{|c|}{$24 \%$} \\
\hline $\begin{array}{l}\text { Requests for } \\
\text { legalisation }\end{array}$ & & & & $7 \%$ & & & & $7 \%$ & & \\
\hline
\end{tabular}

Source: Compiled by the author based on UNODC and Government of Colombia, 'Alluvial Gold

Exploitation Evidences from Remote Sensing 2016'.

The complexity of the situation is illustrated by the fact that coca plantations were also observed in 41 per cent of the areas where EVOA was present, further increasing the vulnerability of the inhabitants of these areas plagued by poverty, marginality and activity of armed, organised crime groups. These figures coincide with research, revealing how illegal mining has spread beyond the Andean region to Venezuela and Brazil and become a more lucrative criminal economy than drug trafficking during the last half-decade. ${ }^{44}$

The devastating impact of various illegal activities on the environment is also illustrated by a study highlighting the loss of forest area, which in 2020 increased by 8 per cent compared to the previous year, reaching 171,685 ha nationwide. The most affected areas with 70 per cent of the total loss are located in 5 departments of the Amazon region

44 The Global Initiative against Transnational Organized Crime, 'El Crimen Organizado y la Minería Ilegal de Oro en América Latina’, April 2016. 
Meta, Caquetá, Guaviare, Putumayo and Antioquia. There are five delineated causes behind environmental crime, all of which are linked to land grabbing: expansion of agricultural activity into protected areas with clearing forest for cattle ranching, illicit crop cultivation, illegal mining and road construction and logging. In the three departments of the Amazon region of Colombia, deforestation for land grabbing, which will be used for livestock, coca cultivation and agricultural activities, increased by 80 per cent in 2020 compared to the previous year. This phenomenon is sustained by the fact that there are different interests and power asymmetry among the various local actors involved, such as politicians, the private sector, communities and organised environmental criminal groups. ${ }^{45}$ Illicit crop cultivation is a driver not just for deforestation, but for violence as well. Around 13,000 hectares new areas were cleared for coca crops mainly in Putumayo and Antioquia departments, which are among the most affected ones with violent acts as well. Especially Antioquia, where a 27.5 per cent increase is documented in coca crops cultivation from 2019. At the same time, Putumayo and Caquetá continue to fight against illicit crop cultivation even after the pandemic lockdown and despite eradication efforts. ${ }^{46}$

\section{Conclusion}

The case of Colombia shows the complex interplay of different threats, local factors and dynamics, and the crucial role of the institutional failure in sustaining the analysed processes and their cumulative impact on vulnerable social groups. In the current climate emergency situation, which is directly linked to other issues such as economic insecurity, rising inequality in many aspects, especially affecting ethnic minorities, environmental activists and human rights defenders play an essential and visible role. Violence against them can be considered an indicator. Despite the rising number of atrocities against the activists, governmental agencies and businesses fail to protect them, especially from those engaged in illegal economic activities due to poor law enforcement, non-compliance and high corruption at the local level. Overall, decreasing the levels of violence does not only need to include some further variables into the analysis but the application of a comprehensive, holistic approach offered by the complementarity of the human security and human development concepts.

I argue that violence is a phenomenon affecting the lives and opportunities of all citizens in varying degrees in terms of territorial, ethnic and social distribution. Measuring its impact should be a particularly important element in the multidimensional poverty measurement, based on normative choices by decision-makers. The measurement of the violence dimension can be better understood as a threat from the citizen security perspective. In most cases, violence and the threat of personal and citizen security is related to economic, environmental and livelihood threats. This study points to the need

45 Instituto de Hidrología, Meteorología y Estudios Ambientales, 'Resultados Del Monitoreo de Deforestación 2020', 2021.

46 UNODC and Government of Colombia, 'Colombia: Monitoreo de Territorios Afectados Por Cultivos Ilícitos 2020', July 2021. 
for further research to analyse processes at the municipality level related to violence and other dimensions of poverty with a special focus on departments inhabited by AfroColombian and indigenous communities, where most illegal activities and legal mining concentrate, as well.

An appropriate measurement can lead to design public policies with an impact on the triad of freedom from fear, freedom from want and living in dignity. They are intertwined aspects - none of them can be achieved without the other two conditions.

Change processes in the Colombian context require the elimination of the historically inherited mistrust between the state and marginalised social groups, a comprehensive rural development approach to help accomplish the points of agreement with the FARC through community building and offering economic alternatives for illegal activities. Ensuring and implementing proper institutions linked to many forms of security, with a wider range of livelihood opportunities, can reduce citizens' vulnerability. Weak institutions, which are in many cases historically inherited and further weakened by governance failures, have serious consequences and can reduce the impact of well-designed and useful public policies. As the case of Colombia has illustrated, political will throughout consecutive presidential cycles is an essential requirement for changing complex processes.

\section{References}

Alkire, Sabina and James Foster, 'Counting and Multidimensional Poverty Measurement'. Journal of Public Economics 95, no 7-8 (2011), 476-487. Online: https://doi. org/10.1016/j.jpubeco.2010.11.006

Angulo Salazar, Roberto Carlos, Yadira Díaz Cuervo and Renata Pardo, Índice de Pobreza Multidimensional Para Colombia. Archivos de Economía, Departamento Nacional de Planeación, 7 November 2011. Online: https://ideas.repec.org/p/col/000118/009228.html

Arboleda, Jairo A, Patti L Petesch and James Blackburn, Voices of the Poor in Colombia: Strengthening Livelihoods, Families, and Communities. Washington, D.C.: World Bank Publications, 2004. Online: https://doi.org/10.1596/0-8213-5802-2

Bagley, Bruce M and Jonathan D Rosen, Colombia's Political Economy at the Outset of the Twenty-First Century: From Uribe to Santos and Beyond. Lexington Books, 2015.

Boltvinik, Julio, 'Medición Multidimensional de La Pobreza. AL de Precursora a Rezagada.' Revista Sociedad y Equidad, no 5 (2013). Online: https://doi.org/10.5354/07189990.2013.26337

Bourdieu, Pierre, 'Sur le pouvoir symbolique’. Annales 32, no 3 (1977), 405-411. Online: https://doi.org/10.3406/ahess.1977.293828

Brinks, Daniel M, Steven Levitsky and María Victoria Murillo, The Politics of Institutional Weakness in Latin America. Cambridge University Press, 2020. Online: https://doi. org/10.1017/9781108776608

Business and Human Rights Resource Center, 'Business and Human Rights Defenders in Colombia', March 2020.

Collier, Paul, The Bottom Billion: Why the Poorest Countries are Failing and What Can Be Done About It. New York: Oxford University Press, 2008. 
Commission on Human Security, Human Security Now: Protecting Empowering People. UN, 2003.

DANE. Online: https://dane.gov.co/index.php/estadisticas-por-tema/pobreza-y-condiciones-devida/pobreza-y-desigualdad/pobreza-monetaria-y-multidimensional-en-colombia-2019

Galtung, Johan, Theories of Peace. A Synthetic Approach to Peace Thinking. Oslo, International Peace Research Institute, 1967.

Galtung, Johan, 'Violence, Peace, and Peace Research’. Journal of Peace Research 6, no 3 (1969), 167-191. Online: https://doi.org/10.1177/002234336900600301

Gasper, Des and Oscar A Gómez, 'Human Security Thinking in Practice: "Personal Security”, “Citizen Security” and Comprehensive Mappings’. Contemporary Politics 21, no 1 (2015). Online: https://doi.org/10.1080/13569775.2014.993906

Global Witness, 'Defending Tomorrow', July 2020.

Goldhub. Online: www.gold.org/goldhub/data/gold-prices; www.gold.org/goldhub/data/ historical-mine-production

Haq, Mahbub ul, Reflections on Human Development. Oxford University Press, 1995.

Institute for Economics and Peace, Global Peace Index 2021: Measuring Peace in a Complex World. Sydney: June 2021. Online: http://visionofhumanity.org/reports

Instituto de Hidrología, Meteorología y Estudios Ambientales, 'Resultados Del Monitoreo de Deforestación 2020’, 2021.

Global Witness, 'Investigations and Advocacy for Climate Justice and Civic Freedoms', s. a. Online: www.globalwitness.org/en/

Kaldor, Mary, New and Old Wars: Organised Violence in a Global Era. Polity Press, 2012. Online: $w w w . p o l i t y . c o . u k / b o o k . a s p ? r e f=9780745655635$

Kanbur, Ravi and Andy Sumner, 'Poor Countries or Poor People? Development Assistance and the New Geography of Global Poverty'. Journal of International Development 24, no 6 (2012), 686-695. Online: https://doi.org/10.1002/jid.2861

Knoema, ‘Colombia - Total Primary Coal Production', 2020. Online: https://knoema.com//atlas/ Colombia/topics/Energy/Coal/Primary-coal-production

Narayan, Deepa, Raj Patel, Kai Schafft, Anne Rademacher and Sarah Koch-Schulte, Voices of the Poor: Can Anyone Hear Us? World Bank, 2000. Online: https://doi.org/10.1596/01952-1601-6

Policía Nacional de Colombia, ‘Policía Nacional de Colombia’. Online: www.policia.gov.co/

OECD, 'Portraits of Informality’. Online: https://doi.org/10.1787/ee0642f5-en

Rothschild, Emma, 'What Is Security?’ Daedalus 124, no 3 (1995), 53-98.

Sen, Amartya, Development as Freedom. Oxford - New York: Oxford University Press, 1999.

SIADDHH, ‘La Mala Hora Informe Anual 2020’. Online: https://drive.google.com/file/d/1ZeGofhR6k0c23oUCVN-ZlWrEMPH03JV/view

Stiglitz, Joseph E, Amartya Sen and Jean Fitoussi, The Measurement of Economic Performance and Social Progress Revisited. Paris: Commission on the Measurement of Economic Performance and Social Progress, 2009.

The Global Initiative against Transnational Organized Crime, 'El Crimen Organizado y la Minería Ilegal de Oro en América Latina’, April 2016. 
UN, 'Transforming Our World: The 2030 Agenda for Sustainable Development: Sustainable Development Knowledge Platform’, 2015. Online: https://sustainabledevelopment.un.org/ post2015/transformingourworld

UNCTAD, World Investment Report 2020: International Production beyond the Pandemic. Geneva - New York: United Nations, 2020.

UNDP, Human Development Report 1994. New York: Oxford University Press, 1994.

UNDP, Mainstreaming Climate Change in Colombia. New York: UNDP Project Team, 2010.

UN HRC, Situation of Human Rights in Colombia - Report of the United Nations High Commissioner for Human Rights (A/HRC/46/76). UN, February 2021.

United Nations, Human Development Report 1990. Published for the United Nations (New York) Development Programme. New York: Oxford University Press, 1990.

UNODC, Global Study on Homicide 2019: Executive Summary. United Nations Office on Drugs and Crime, 2019.

UNODC and Government of Colombia, 'Alluvial Gold Exploitation Evidences from Remote Sensing 2016', May 2018.

UNODC and Government of Colombia, 'Colombia: Monitoreo de Territorios Afectados Por Cultivos Ilícitos 2020’, July 2021.

UNODC and Government of Colombia, 'Colombia Explotación de Oro de Aluvión Evidencias a Partir de Percepción Remota 2020’, July 2021.

WMR, World Migration Report 2020. Geneva: International Organization for Migration, 2020. Online: https://publications.iom.int/books/world-migration-report-2020 